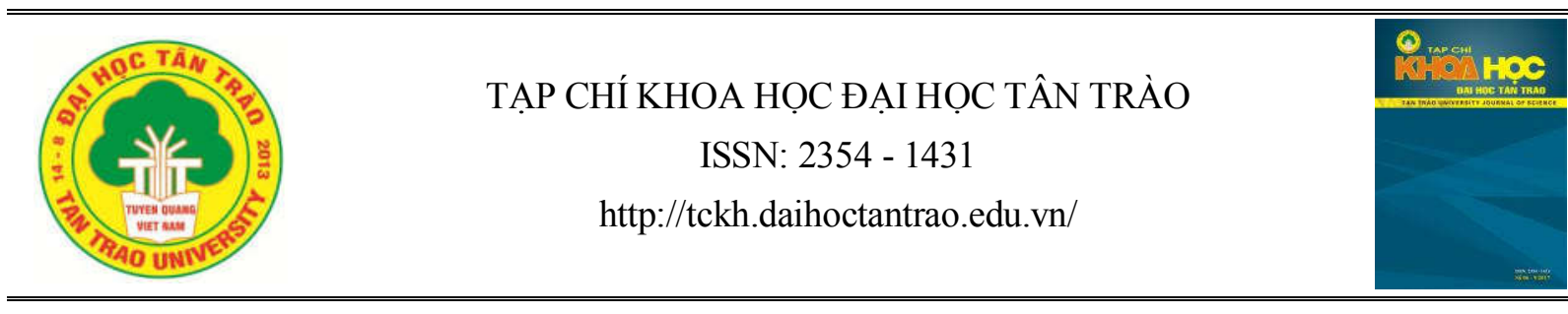

\title{
Biếu tặng trong thời kỳ sinh đẻ của người Tày, Nùng một hình thức thiết lập và duy trì mạng lưới xã hội
}

\author{
LýViết Trường ${ }^{a^{*}}$ \\ a Viện Việt Nam học và Khoa học Phát triển \\ *Email: lyviettruongls@gmail.com
}

\section{Thông tin bài viết}

Ngày nhận bài:

27/8/2018

Ngày duyệt đăng:

$10 / 6 / 2019$

Tù khóa:

Biếu tặng trong sinh đẻ;

có đi có lại; mạng lưới quan

hẹ xã hội

\section{Tóm tắt}

Bài viết khảo sát mối quan hệ biếu tặng của người Tày, Nùng trong thời kỳ sinh đẻ và vai trò của nó trong quá trình thiết lập, duy trì mạng lưới quan hệ xã hội của người dân ở xã Thạch Đạn, một xã điển hình của quá trình cộng cư và giao lưu văn hóa Tày, Nùng. Kế thừa luận điểm của Marcel Mauss trong công trình "Luận về biếu tặng....", ông cho rằng biếu tặng một mặt là sự bắt buộc phải tặng quà và mặt kia là sự bắt buộc phải nhận quà, từ chối tặng quà cũng có nghĩa là từ chối một mối quan hệ. Kết quả nghiên cứu cho thấy trong thời kỳ sinh đẻ, mối quan hệ biếu tặng diễn ra theo nguyên tắc "bát mưng bát câu" (có đi có lại). Biếu tặng trong thời kỳ sinh đẻ là một cách để người Tày, Nùng xã Thạch Đạn thiết lập, duy trì và làm mới vốn xã hội của mình.

\section{Tổng quan địa bàn, đối tượng nghiên cứu và phương pháp tiếp cận}

\subsection{Xã Thạch Đạn: địa bàn cộng cu của hai dân} tộc Tày và Nùng

Xã Thạch Đạn nằm ở vị trí: 21051'14" vĩ Bắc và $106^{0} 45^{\prime} 16^{\prime}$ ' kinh Đông. Diện tích tự nhiên của xã là: 3.623,42 ha. Phía Bắc giáp xã Bảo Lâm, phía Nam giáp các xã Hợp Thành và Hòa Cư, phía Đông giáp các xã Thanh Lòa và Lộc Yên, phía Tây giáp các xã Thụy Hùng và Hoàng Đồng.

Ngược dòng lịch sử, thời Văn Lang - Âu Lạc vùng đất xã Thạch Đạn thuộc bộ Lục Hải, đây là một trong 15 bộ thời kỳ đó. Bộ Lục Hải giáp với các bộ Vũ Định, Văn Lang, Chu Diên, Phúc Lộc, Vũ Ninh, Ninh Hải và phần đất của Trung Quốc. Suốt một nghìn năm Bắc Thuộc vùng đất xã Thạch Đạn là 1 trong 40 châu Ky My, thời kỳ này vùng đất Thạch Đạn nói riêng và eáe châu Ky My là những nơi biên giới xa xôi, chính quyền thống trị phương Bắc không thống trị trực tiếp được, nên để cho các tù trưởng người địa phương quản lý.

Đến thời Lý (1009 - 1225), vùng đất Thạch Đạn thuộc lộ Châu Lạng. Thời Đầu thời Trần (1225 - 1400), vùng đất Thạch Đạn thuộc trấn Lạng Giang, năm Quang Thái thứ 10 (1397) đổi là trấn Lạng Sơn. Thời thuộc Minh (1414 - 1427), vùng đất Thạch Đạn thuộc phủ Lạng Sơn. Đến thời Lê (1428 - 1527), vùng đất Thạch Đạn thuộc thừa tuyên Lạng Sơn, lúc này đạo Lạng Sơn có 1 phủ và 6 châu. Thời Đồng Khánh (1886 - 1888), Thạch Đạn là một vùng đất thuộc tổng Trừ Trĩ, châu Thoát Lãng, có tên gọi là Thạch $\mathrm{Bi}^{1}$ (Hoàng Giáp Hoàng Páo 2012: 41-42). Đầu thế kỷ XX, tên xã chuyển từ Thạch Bi sang Thạch Đạn, thuộc châu Văn Uyên. Thời đó, xã có 22 bản: Cốc Pục, Khuổi Phầy, Thâm Sa, Bản Cưởm, Bản Tàn, Cốc Slé, Mu Ngạp, Còn Quyền, Bản Đẩy, Bản Áng, Nà Lẹng, Bản Mạc, Nà Nhàn, Nà Sla, Pác Roọc, Nà Piao, Bản Roọc, Chang Khuổi, Bản Phường, Nà Vá, Nà Mon, Thâm Cùm (Vũ Thị Minh Hương - Nguyễn Văn Nguyên - Philippe Papin 1999: 599-600).

Trải qua thăng trầm lịch sử tên gọi xã Thạch Đạn cũng đã nhiều lần thay đổi. Năm 1982, xã Thạch Đạn

\footnotetext{
${ }^{1}$ Tổng Trừ Trĩ có 10 xã, phố, trại: xã Trừ Trì, xã Hoàng Đồng, xã Vĩnh Trại, xã Thạch Đạn, xã Hòa Cư, trại Khôn Lại, trại Cốc Chấn, phố Khâu Lư (Kỳ Lừa), phố Nam Nhai, phố Vị. Riêng tổng Trừ Trĩ ở xen vào các tổng Vĩnh Dật, Uyên Lệ (Cốt), Hành Lư của châu Văn Uyên.
} 
sáp nhập với xã Bảo Lâm thành xã Thạch Lâm, tên gọi Thạch Lâm là tên ghép của hai xã Thạch Đạn và Bảo Lâm. Đến năm 1986, xã Thạch Lâm chia tách lại thành 2 xã là Thạch Đạn và Bảo Lâm². Trên địa bàn xã Thạch Đạn, hai dân tộc Tày và Nùng đã có quá trình cộng cư lâu đời và tạo ra một nền văn hóa đa dạng giàu bản sắc. Chủ nhân đầu tiên của các bản Nà Lẹng, Nà Sla, Khon Cuổng là người Nùng Phàn Slình; còn các thôn Bản Cưởm, Bản Đẩy, Bản Áng là địa bàn sinh sống của những người Tày gốc Kinh (keo ké piến Tày); người Nùng Cháo là chủ nhân của thôn Bản Roọc; người Tày gốc là chủ nhân của thôn Nà Mon và Bản Mạc)... Trải qua thời gian lịch sử biến đổi, tại các thôn/bản các nhóm dân tộc đã di chuyển đến sinh sống xen cài (Lý Viết Trường 2018: 20-21).

Dân cư xã Thạch Đạn chủ yếu là người Nùng và Tày. Tính đến tháng 3/2016 xã có 8 thôn (Bản Cưởm, Còn Quyền, Bản Đẩy, Nà Mon, Nà Lệnh, Bản Roọc, Nà Sla, Khon Cuổng), 674 hộ với 2.921 nhân khẩu. Trong đó dân tộc Nùng chiếm 74,7\%, dân tộc Tày chiếm $25,1 \%$, dân tộc Kinh chiếm $0,2 \%{ }^{3}$. Với lịch sử cộng cư lâu đời người dân xã Thạch Đạn có một nền văn hóa rất đa dạng, mạng lưới quan hệ xã hội trong nghi lễ vòng đời nói chung và trong thời kỳ sinh đẻ nói riêng là một khía cạnh rất quan trọng trong đời sống người dân.

\subsection{Tổng quan nghiên cúu}

Nghi lễ thời kỳ sinh đẻ nói riêng và nghi lễ vòng đời nói chung đã được các nhà nghiên cứu đề cập trong các công trình của mình. Các tác giả Lã Văn Lô - Đặng Nghiêm Vạn (1968), Ma Tiến Dũng (1980), Hoàng Nam (1992), Viện Dân tộc học (1992), Ủy ban nhân dân tỉnh Lạng Sơn (1999)... trình bày một cách khái quát tất cả các nghi lễ trong chu kỳ đời người, rồi đánh giá vai trò của từng nghi lễ đối với từng thời kỳ trưởng thành của con người. Thời kỳ ấu thơ có các nghi lễ đầy tháng, với các thủ tục lập bàn thờ mụ, đặt tên con, đây là nghi lễ khởi đầu của chu kỳ đời người (Lã Văn Lô Đặng Nghiêm Vạn 1968: 98-99; Lý Viết Trường 2017a: 30; Lý Viết Trường 2017b: 31-32).

Ở Việt Nam hiện nay nghiên cứu về biếu tặng đang ngày càng được nhiều nhà nghiên cứu quan tâm. Các nhà nghiên cứu đều có chung nhận định biếu tặng là một quá trình có đi có lại, biếu tặng là cách tương trợ

\footnotetext{
2 Trích Quyết định số 138-HĐBT của Hội đồng Bộ trưởng về việc chia xã Thạch Lâm thành hai xã Thạch Đạn và Bảo Lâm thuộc huyện Cao Lộc, tỉnh Lang Son, số 138-HĐBT, tr.1.

${ }^{3}$ Số người Kinh này chủ yếu là người đến làm dâu từ các địa phương khác.
}

nhằm duy trì mạng lưới quan hệ xã hội. Tuy nhiên các nhà nghiên cứu hiện nay mới chủ yếu đề cập đến biếu tặng và vốn xã hội của người Việt, còn biếu tặng và vốn xã hội ở cộng đồng các dân tộc thiểu số vẫn chưa được quan tâm nghiên cứu đúng mức.

Trong khoảng gần 10 năm trở lại đây chúng tôi nhận thấy vấn đề biếu tặng và tương trợ của người Tày, Nùng mới bắt đầu được quan tâm nghiên cứu. Những người đi đầu trong nghiên cứu biếu tặng và tương trợ cộng đồng là các nhà nghiên cứu Nguyễn Anh Tuấn (2011), Lê Minh Anh (2012). Hai tác giả đã vận dụng lý thuyết vốn xã hội để tiếp cận vấn đề biếu tặng và tương trợ cộng đồng trong việc thiết lập mạng lưới quan hệ xã hội của người Tày, Nùng. Tuy nhiên các tác giả cũng chỉ mới đề cập đến biếu tặng và tương trợ trong cưới xin và tang ma, mà chưa nhắc đến tục biếu tặng khi sinh nở. Nghiên cứu này của chúng tôi thực hiện nhằm khỏa lấp khoảng trống đã chỉ ra ở trên, đồng thời đưa ra những luận giải khoa học về tục biếu tặng khi sinh của người Tày, Nùng xã Thạch Đạn và vai trò của nó trong việc duy trì mạng lưới quan hệ xã hội.

\subsection{Lý thuyết và phương pháp tiếp cận}

Bài viết này chúng tôi không đi sâu vào nghiên cứu sinh đẻ theo cách thức tiến hành những luật lệ, hay những quy định của người dân xung quanh vấn đề sinh đẻ mà chúng tôi sử dụng khái niệm biếu tặng của Marcel Mauss để tiếp cận vấn đề biếu tặng và tương trợ cộng đồng. Trong công trình kinh điển về biếu tặng mang tên "Luận về biết tặng: hình thức và lý do của sụ" trao đổi trong các xã hội cổ xư" Marcel Mauss đã xem biếu tặng như một hành động có đi có lại, "người nhận quà hôm nay sẽ là nguời biếu quà lần sau đó" (Marcel Mauss 2015: 240), và biếu tặng chính là hình thức để xây dựng cho mình mạng lưới quan hệ xã hội.

Cùng với khái niệm biếu tặng, lý thuyết mạng lưới quan hệ xã hội cũng được chúng tôi sử dụng trong nghiên cứu này. Mạng lưới quan hệ xã hội là một trong những thành tố cơ bản cấu thành nên vốn xã hội, hiện nay khái niệm này đang được sử dụng rộng rãi trong nghiên cứu Khoa học Xã hội ở Việt Nam (Nguyễn Quý Thanh (chủ biên) 2016: 59). Hiện nay có nhiều định nghĩa về mạng lưới xã hội, mỗi người dựa trên một cách tiếp cận lại đưa ra một góc nhìn khác nhau; trong bài viết này chúng tôi dựa vào khái niệm của các tác giả Nguyễn Quý Thanh để triển khai nghiên cứu: mạng lưới quan hệ xã hội có thể được xem là một tập hợp các mối quan hệ liên kết, đan xen và bao bọc xung quanh chủ thể, tạo ra không gian xã hội của chủ thể. Cá nhân 
với tư cách là chủ thể tương tác, thông qua mạng lưới các quan hệ xã hội tạo ra các nguồn lực tiềm tàng để cá nhân khai thác và sử dụng trong quá trình hướng đích của mình (Nguyễn Quý Thanh (chủ biên) 2016: 60). Trong mạng lưới quan hệ xã hội lòng tin đóng vai trò rất quan trọng, tác động đến quá trình vận hành quan hệ xã hội, không có lòng tin xã hội thì không có mạng lưới quan hệ xã hội (Nguyễn Quý Thanh (chủ biên) 2016: 82).

Điền dã dân tộc học là phương pháp nghiên cứu được chúng tôi sử dụng trong quá trình khảo sát tại địa bàn nghiên cứu. Tại địa bàn nghiên cứu chúng tôi đã sử dụng những công cụ sau: quan sát tham gia, phỏng vấn sâu, thảo luận nhóm. Do tác giả là người Nùng sống ở địa bàn nghiên cứu, nên từ nhỏ tôi đã được chứng kiến các hoạt động tương trợ trong nghi lễ vòng đời nói chung và thời kỳ sinh đẻ nói riêng.

Với lợi thế là người địa phương, nên trong quá trình khảo sát tôi gặp nhiều thuận lợi vì bản thân là người địa phương, sử dụng được ngôn ngữ Nùng Phàn Slình nên có điều kiện để hiểu rõ hơn về đối tượng nghiên cứu; nhưng cũng gặp không ít khó khăn do cùng một lúc trong một nghi lễ có nhiều sự kiện diễn ra liên tiếp, nên không thể quan sát được hết tất cả. Chính vì những hạn chế của quan sát tham gia ấy nên trong quá trình điền dã, chúng tôi đã tiến hành phỏng vấn sâu với những đối tượng thuộc các loại hình nghề nghiệp ở các độ tuổi khác nhau..

Sau khi thu thập được những thông tin từ những phỏng vấn sâu chúng tôi thực hiện thảo luận nhóm với mục đích kiểm chứng các thông tin mà trong quá trình phỏng vấn sâu chúng tôi thu được, đồng thời qua những cuộc thảo luận nhóm chúng tôi làm rõ nhiều thông tin liên quan đến mối quan hệ tương trợ và cố kết cộng đồng tộc người qua lời kể. Chúng tôi tiến hành nhiều thảo luận nhóm, mỗi cuộc có từ $5-7$ người tham gia.

\section{Biếu tặng trong thời kỳ sinh đẻ}

Trong bài viết này biếu tặng trong sinh đẻ được hiểu là những món quà mà họ hàng, hàng xóm, bạn bè... mang đến biếu tặng khi trong gia đình có người sinh con. Việc biếu tặng thường diễn ra từ khi người mẹ sinh em bé đến khi em bé làm lễ đầy tháng (an va), thời gian tặng qùa sớm hay muộn phụ thuộc vào khoảng cách địa lý giữa người tặng và người nhận quà. Những người thực hiện tương trợ bao gồm: họ hàng thân thích, hàng xóm gần gũi và bạn bè thân thiết. Người Nùng Phàn Slình quan niệm người mang quà đến "duoong eng" là người có mối quan hệ gần gũi. Quan niệm như vậy, nên họ hàng lập nghiệp ở xa, di cư vào sinh sống ở Tây Nguyên, hay lập nghiệp ở tỉnh khác, khi nghe tin có người thân ở quê cũ sinh con vẫn nhờ người thân mang giúp quà biếu (Lý Viết Trường 2018: 51-52).

Con cái là cuộc sống của cha mẹ, vậy nên từ khi mang thai đến khi đứa bé chào đời cả mẹ và bé đều được gia đình, họ hàng và người thân chăm lo từ bữa ăn đến giấc ngủ. "Khi bé còn trong tháng, nhiều nguời bè bạn quen thân của gia đình, của bố cháu, của mẹ cháu đến thăm, cho quà. Khi người mẹ sinh con nguoòi Tày, Nùng thuờng cắm truớc cửa nhà một cành cây để thông báo vói bà con hàng xóm biết gia đình minh đã có thành viên mói, cũng đồng thòi tránh ma quỷ quấy phá em bé" (Nhiều tác giả 1994: 113).

Khi sinh con người mẹ cần bổ sung rất nhiều chất dinh dưỡng để hồi sức và có sữa nuôi con, nên thức ăn chính của người mẹ phải là những món chứa nhiều chất dinh dưỡng như gà, chân giò, gạo nếp... Tuy nhiên, do đời sống đồng bào còn khó khăn nên không có điều kiện để chăm lo cho sản phụ và đứa trẻ, vì vậy tập tục trợ giúp trong thời kỳ sinh đẻ đã có từ rất lâu đời và hiện nay người Tày, Nùng vẫn tiếp tục duy trì. "Quà thăm người đẻ có thể là chân giò lợn, gà mái ghẹ, thịt lợn, gạo nếp, nuơuu, gùng nghệ... hoặc cho quà bé nhu quần áo so sinh: tã, lót, khăn, mặt bông to, mũ so sinh..." (Nhiều tác giả 1994: 113).

Biếu tặng khi trong bản - trong họ có nguoòi sinh là một tập tuc tốt đẹp đã có tù khi tôi còn nhỏ, đến nay mọi nguời vẫn duy trì tục biếu tặng, và tục này vẫn không khác mấy so với ngày xua, duy chi có một điểm khác là nhiều món quà hơn (Sèn Suồng, dân tộc Nùng, sinh năm 1932, bản Nà Lẹng, tháng 02/2016).

Người thực hiện biếu tặng thường là nữ giới. Bởi lẽ phụ nữ thường là người có kinh nghiệm trong việc chăm sóc con nhỏ mới sinh, trong việc chăm sóc sức khỏe bà mẹ mới đẻ. Ngoài tặng quà có giá trị vật chất người ta còn tỏ ra quan tâm nhau, hỏi han và chia sẻ những kinh nghiệm từng trải cho nhau. Rõ ràng những việc như thế thì nữ giới là phù hợp nhất.

Việc biếu tặng không có quy định cụ thể về lễ vật và thời gian, nhưng dù không có quy định nhưng cứ trong họ ngoài bản có người sinh đẻ là người ta lại cảm thấy mình có trách nhiệm phải tương trợ gia đình đó cả vật chất lẫn tinh thần. Người Tày, Nùng bản Nà Lẹng quan niệm việc biếu tặng là "bát mung bát câu" (có đi có lại), nghĩa là họ hàng có người sinh con người Tày, Nùng có trách nhiệm mang quà đến tặng cho bà mẹ và đứa trẻ với mong muốn giúp đỡ đứa trẻ phần nào trong 
những năm tháng đầu đời. Việc biếu quà mặc dù không ai ép buộc, nhưng tập tục đã có từ lâu đời, nếu ai quên hoặc cố tình quên không biếu tặng thì mối quan hệ giữa họ và gia đình có người sinh con sẽ trở nên tồi tệ.

Những món quà biếu tặng không dừng lại ở những món quà vật chất thông thường như ta nhìn thấy mà nó đã trở thành vật gửi gắm tấm lòng của những người họ hàng, bạn bè dành cho nhau. Thông qua biếu tặng người ta có thể nhận biết mối quan hệ khăng khít giữa người đi biếu và người được biếu.

Biếu tặng ngưòi ta khi sinh cũng giống nhu gưi quà cho họ hàng để sau này khi gia đình mình có cháu sẽ được họ hàng, bạn bè biếu tặng lại (Mạy Ngạn, dân tộc Tày, sinh năm 1968, bản Nà Lẹng, tháng 02/2016).

Số lượng người thực hiện tương trợ phụ thuộc vào việc đó là con cả hay con thứ, con cả được biếu nhiều nhất còn các con thứ sẽ được biếu ít hơn. Thời điểm sinh con đầu lòng, anh Chới $\mathrm{Kyy}^{4}$ được 22 người tương trợ, đến khi sinh con thứ 2 số người biếu giảm xuống còn 14 người. Năm 2014, khi vợ chú Hờn Cau sinh con, gia đình chú được 25 người biếu quà. Trong đó, tỷ lệ tương trợ của họ hàng chiếm $90,1 \%$ (số lượng họ nội chiếm $40,5 \%$, họ ngoại chiếm $49,6 \%$ ); chỉ có $9,9 \%$ số lượng người tương trợ là hàng xóm và bạn bè (Lý Viết Trường 2017a). Lượng người tương trợ trong lễ “durong eng" (thăm trẻ) ngoài phụ thuộc vào con trưởng, con thứ, còn phụ thuộc vào vào quy mô lớn nhỏ của họ hàng mà chủ thể sở hữu. Điều này được chứng minh khi vợ anh Bẳm và vợ anh Khuông đều là người cùng bản ${ }^{5}$, đều sinh con thứ, nhưng do họ hàng anh Khuông đông nên anh được 12 người tương trợ, còn anh Bẳm do ít họ hàng nên chỉ có 7 người thực hiện tương trợ (Lý Viết Trường 2017a).

Trong thời kỳ thơ ấu, người sản phụ vừa sinh con cơ thể còn yếu, nên người mẹ phải kiêng kỵ rất nhiều thứ như: kiêng ra gió, kiêng xuống nước, kiêng giặt giũ, kiêng làm công việc nặng, kiêng lại gần những thứ có nguy cơ gây hại cho cơ thể... Những người phụ nữ từng trải qua sinh nở, hơn ai hết là người hiểu rõ những kiêng kỵ trong phòng tránh bệnh tật và kỹ năng nuôi con. Vì lợi thế kinh nghiệm từng trải, nên người thực hiện biếu quà trong lễ "durong eng” (thăm trẻ) thường là nữ giới đã từng sinh con. Bởi như phân tích ở trên, khi

\footnotetext{
${ }^{4}$ Tên của các nhân vật trong bài viết đã được mã hoá

5 Anh Khuông và anh Bẳm cùng ở bản Nà Lẹng, thôn Nà Lệnh, xã Thạch Đạn. Tính đến năm 2017, bản có 50 hộ, với nhiều dòng họ khác nhau như Lý, Đinh, Nông, Hứa, Triệu, Hoàng, Chu, Lăng, Hà... Trong đó họ Đinh đông hộ nhất, với 11 hộ (anh Khuôn là người họ Đinh); họ đông thứ hai là họ Lý với 9 hộ, họ ít hộ nhất là họ Hà (gia đình anh Bẳm).
}

họ đến thăm trẻ ngoài tặng quà có giá trị vật chất người ta còn hỏi han và chia sẻ những kinh nghiệm từng trải cho nhau.

Phụ nũ thường là người mang quà đến biếu trong lễ "duoong eng", vì phu nũ sẽ thuận tiện hơn trong việc tiếp súc với sản phu và đứa trẻ. Hơn nũa, phu nũ là ngườ đã có kinh nghiệm liên quan đến việc sinh nở, nên có thể truyền lại nhũng kinh nghiệm của minh cho ngườ mẹ trẻ [Thâm Bay, sinh năm 1964, bản Thông Cùm, tháng 6/2017].

Khi nhận lại những món quà biếu tặng từ họ hàng, bà con hàng xóm và bạn bè thì gia đình người nhận sẽ ghi nhớ xem những ai đã biếu tặng gia đình mình để đến khi gia đình đó sinh con thì mình lại mang quà đến biếu tặng họ. Đó là mối quan hệ tương trợ có đi có lại, người ta thường ghi lại tên những người đã biếu tặng mình trong cuốn sổ gia đình để khi sau này gia đình họ có người sinh con mình còn biếu lại. Nếu như gia đình nào nhận quà rồi mà quên, hoặc cố tình không mang quà đến tặng lại người đã từng biếu khi gia đình có người sinh thì người đã từng tặng sẽ đánh giá người đã nhận không biết đạo lý làm người và từ đó hai bên rất có thể mối quan hệ giữa hai gia đình sẽ nhạt nhòa dần, hoặc có thể hai gia đình sẽ chấm dứt mối quan hệ biếu tặng qua lại. Những gia đình nhận quà không thực hiện biếu tặng lại sẽ bị mọi người coi thường, bởi lẽ những người như thế là những người không thực hiện đúng nguyên tắc có đi có lại, họ tự tách mình ra khỏi cộng đồng, đến khi gia đình có việc họ sẽ không có nơi nương nhờ.

Cùng với sự biến đổi của đời sống kinh tế, trong bối cảnh hội nhập hiện nay tặng phẩm của người Nùng Phàn Slình dùng cho việc thăm thân đang có xu hướng thay quà hiện vật bằng tiền (Lê Minh Anh 2013: 433). Việc thay quà tương trợ bằng tiền bắt đầu xuất hiện khoảng 10 năm trước. Qua khảo sát, chúng tôi nhận thấy bản Nà Sla, Khon Cuổng và Thông Cùm người ta vẫn duy trì tương trợ hiện vật; còn bản Nà Lẹng, hiện nay chỉ còn những người họ hàng thân thích (anh em bên nội và họ hàng bên ngoại) duy trì biếu tặng quà bằng hiện vật, còn lại các mối quan hệ khác hầu như đều tương trợ bằng tiền (Lý Viết Trường 2017a: 33).

Trước đây kinh tế khó khăn, gia đinh không có điều kiện để mua thức ăn cho sản phụ, nên người ta mang gà đến biếu, mỗi nguời một con để gia đình ăn dần. Hiện nay, kinh tế khá giả hơn, việc mua bán cũng thuận lợi nên ngườ ta thay vì biếu bằng hiện vật thi biếu bằng tiền cho tiện. Người ta vẫn đến nhà thăm, nhung thay vì 
mang hiện vật đến, nguoòi ta sẽ biếu tiền, khoảng 100 200 nghìn đồng, tùy vào mức độ thân thiết. Nguời ta cũng sợ mang gà tù̀ nhà mình đến biếu, chẳng may gà hàng xóm gia đình minh biếu bị bệnh, nguời ta lại bảo do minh mang gà dịch đến biếu mói khiến dịch lây lan. Nhiều nguời ở trong Nam (Tây Nguyên) biết tin ho hàng có nguoòi sinh, truớc đây nguời ta cũng gọi điện ra nhò̀ họ hàng mua con gà hay chân giò đến biếu, nay chăng cần nhu thế nữa, cứ mang tiền sang biếu luôn. Nhu thế vì̀a giúp cho gia đình có tiền, sản phu thích ăn gì gia đình chủ động mua, tránh lãng phí thức ăn [Thâm Lều, sinh năm 1959, bản Nà Lẹng, tháng 6/2017].

\section{Mạng lưới quan hệ xã hội nhìn từ biếu tặng trong thời kỳ sinh đẻ}

Việc biếu tặng khi sinh không mang trong mình tính thương mại mà là sản phẩm của sự tương trợ cộng đồng, tập tục tương trợ này đã có từ rất lâu đời và vẫn được duy trì trong đời sống hiện nay. Người Tày, Nùng có câu diễn ngôn "không ai sống một mình trên đời này”, bởi vậy biếu tặng trong sinh đẻ là một chiến lược để thiết lập mạng lưới quan hệ xã hội. Mạng lưới quan hệ xã hội là một tập hợp các mối quan hệ liên kết, đan xen và bao bọc xung quanh chủ thể, tạo ra không gian xã hội của chủ thể. Các cá nhân với tư cách là thành viên của mạng lưới xã hội có thể dựa vào mạng lưới xã hội để tạo nguồn lực tiềm tàng trong quá trình hướng đích của mình (Nguyễn Quý Thanh chủ biên 2016: 60). Bourdieu nhấn mạnh mạng lưới xã hội không phải một thứ trời cho, mà phải được tạo dựng thông qua các chiến lược đầu tư nhằm thể chế hóa các quan hệ nhóm để có thể dùng làm nguồn gốc đáng tin cậy, sản sinh ra các điều lợi khác (Alejandro Portes 2014: 138 - 139). Người ta biếu tặng trên tinh thần "pay ngoi" , để lần sau khi gia đình mình có người sinh đẻ sẽ được họ tặng lại. Đồng bào có câu diễn ngôn "Ngù̀n xèn tồ ky / Tào ly. tồ păng"7 "mung dèn cau dài" để nói về mối quan hệ có đi có lại trong biếu tặng, chính yếu có đi có lại là nền tảng để xây dựng lòng tin duy trì mạng lưới quan hệ xã hội.

Biếu tặng trong thời kỳ sinh đẻ là một chuỗi có mở đầu, có duy trì, và nếu như hai bên cảm thấy một mối quan hệ không còn quan trọng thì họ sẽ chấm dứt mạng lưới quan hệ xã hội ấy. Biếu tặng thể hiện sự quan tâm, chia sẻ buồn vui và khó khăn trong cuộc sống. Thông qua quà tặng người ta có thể biết được mối quan hệ

\footnotetext{
${ }^{6}$ Đi gửi

${ }^{7}$ Bạc tiền khắc ghi, đạo lý đáp đền.

${ }^{8}$ Người biếu ta tặng
}

thân sơ giữa người tặng và người được tặng. Số lượng người tặng quà phụ thuộc vào việc đó là con cả hay con thứ, con cả sẽ được họ hàng trợ giúp nhiều nhất còn các con sau sẽ được trợ giúp ít dần.

Qua tìm hiểu tại gia đình anh Lẹng9 ${ }^{9}$, chúng tôi được biết khi sinh con đầu anh được 25 người mang theo quà đến biếu tặng, những người trên chủ yếu là họ hàng, hàng xóm và bạn bè của vợ chồng anh Lẹng. Theo số liệu thống kê thì tương trợ của họ hàng là chủ yếu và chiếm đến $90,1 \%$, trong đó số lượng họ nội chiếm $45,5 \%$ và họ ngoại chiếm $59,1 \%$, còn tương trợ của bạn bè và hàng xóm chỉ chiếm $9,9 \%$. Theo tài liệu khảo sát tại bản Nà Lẹng, xã Thạch Đạn thì số lượng người khảo sát ngoài phụ thuộc vào con trưởng hay con thứ thì lượng biếu tặng còn phụ thuộc vào số lượng họ hàng và số lượng bạn bè của gia đình ấy. Điều này được chứng minh khi vợ anh Bẳm và vợ anh Khuông đều sinh con thứ ba, nhưng do gia đình anh Khuông có nhiều họ hàng và bạn bè hơn nên dù sinh con thứ ba nhưng anh vẫn được 12 người mang quà đến biếu, còn gia đình anh Bẳm do ít họ hàng và mạng lưới quan hệ bạn bè ít nên chỉ có bảy người đến biếu quà. Thông qua phỏng vấn sâu chúng tôi nhận thấy họ hàng là những người đóng vai trò quan trọng trong việc biếu tặng khi sinh, còn những mối quan hệ khác như hàng xóm, bạn bè thường chiếm số ít.

Như vậy một người được coi là có nhiều họ hàng, hàng xóm, bạn bè... khi người đó biết thiết lập, duy trì và mở rộng mạng lưới quan hệ của mình. Ngược lại những người có ít họ hàng, hàng xóm và bạn bè là những người thuộc họ nhỏ có thể vì họ sinh ra trong một dòng họ ít người, hoặc do họ không quan tâm đến việc thiết lập, duy trì và mở rộng mạng lưới quan hệ xã hội.

\section{Kết luận}

Mạng lưới quan hệ xã hội là mối quan hệ giữa các chủ thể tạo thành mạng lưới quan hệ trong không gian xã hội. Chủ thể sở hữu ít hay nhiều mối quan hệ, phạm vi quan hệ rộng hay hẹp phụ thuộc vào nền tảng xuất xứ và ý thức tạo dựng vốn xã hội của bản thân. Lòng tin là yếu tố quan trọng trong việc thiết lập và duy trì mạng lưới quan hệ xã hội. Trong thời kỳ sinh đẻ các chủ thể biếu tặng là những người thuộc mối quan hệ họ hàng thân thích, bạn bè thân thiết... Có đi có lại là nguyên tắc quan trọng trong việc hình thành, duy trì và phát triển mối quan hệ biếu tặng trong sinh đẻ.

\footnotetext{
${ }^{9}$ Tên nhân vật trong bài viết đã được chúng tôi thay đổi
} 
Biếu tặng trong thời kỳ sinh đẻ là một truyền thống văn hóa tốt đẹp của người Tày, Nùng. Cũng như các dân tộc khác, tương trợ cộng đồng đóng vai trò đặc biệt quan trọng trong đời sống con người, đặc biệt là ở những xã hội kém phát triển. Ở cộng đồng Tày, Nùng xã Thạch Đạn truyền thống này đã có từ lâu đời, xuất phát từ nhu cầu tương trợ giữa các cá nhân trong cộng đồng, để giúp nhau cùng vượt qua khó khăn.

Trong bối cảnh hội nhập hiện nay, mối quan hệ biếu tặng trong thời kỳ sinh đẻ vẫn tiếp tục được người Tày, Nùng ở xã Thạch Đạn duy trì và phát triển. Cùng với sự phát triển của kinh tế, xã hội thì mối quan hệ biếu tặng trong thời kỳ sinh đẻ cũng biến đổi theo. Sự biến đổi này diễn ra chủ yếu theo 2 khía cạnh: thứ nhất là thay quà hiện vật bằng tiền, thứ hai là gia tăng số lượng và mở rộng phạm vi người tặng. Nhìn nhận theo chiều rộng của vấn đề, rõ ràng mối quan hệ biếu tặng trong thời kỳ sinh đẻ đóng góp to lớn trong việc phát triển xã hội, củng cố khối đại đoàn kết dân tộc, góp phần đóng góp vào công cuộc xây dựng thành công chương trình nông thôn mới ở xã Thạch Đạn nói riêng và vùng miền núi có đồng bào các dân tộc thiểu số sinh sống nói chung.

\section{TÀI LIỆU THAM KHẢO}

1. Alejandro Portes (2015), "Nguồn vốn xã hội và sự phát triển: chương trình nghị sự tương lai", in trong: Nhiều tác giả (2014), Lòng tin \& Vốn xã hội, Nxb. tri thức.

2. Lê Minh Anh (2012), "Tương trợ cộng đồng trong cưới xin và tang ma của người Nùng Phàn Slình ở huyện Cao Lộc, tỉnh Lạng Sơn", Tạp chí Dân tộc học, số 5 \& 6 .

3. Lê Minh Anh (2013), Quan hệ dòng họ của nguoòi Nùng Phàn Slình (Nghiên cứu ở huyện Cao Lộc, tỉnh Lạng Sơn), Luận án Tiến sĩ Nhân học, Học viện Khoa học Xã hội, H.

4. Ma Tiến Dũng (1980), Khảo sát so bộ tôn giáo tín nguõ̃ng của nguoòi Nùng Phàn Slình ở Chi Lăng Lạng Son: truớc cách mang tháng Tám, Khóa luận Tốt nghiệp Đại học, Đại học Khoa học Xã hội và Nhân văn, Hà Nội.

5. Hoàng Giáp - Hoàng Páo (2012), Văn hóa Lạng Son: địa du chí - văn bia - câu đối, Nxb. Văn hóa Thông tin.

6. Trần Thị Phương Hoa (chủ biên) (2016), Vốn xã hội cái nhìn tù châu $\hat{A} u$, Nxb. Khoa học Xã hội, Hà Nội.
7. Lê Ngọc Hùng (2003), "Lý thuyết và phương pháp tiếp cận mạng lưới xã hội: trường hợp tìm kiếm việc làm của sinh viên", Tạp chí Xã hội học, số 2.

8. Vũ Thị Minh Hương - Nguyễn Văn Nguyên Philippe Papin (1999), Địa danh và tài liệu luu về về làng xã Bắc Kỳ, Nxb. Văn hóa Thông tin, Hà Nội.

9. Lã Văn Lô - Đặng Nghiêm Vạn (1968), So luợc giới thiệu các nhóm dân tộc Tày-Nùng - Thái ở Việt Nam, Nxb. Khoa học Xã hội, Hà Nội.

10. Mauss, Marcel (2015), Luận về biếu tặng: hình thức và lý do của sự trao đổi trong các xã hội cổ so (Nguyễn Tùng dịch), Nxb. Tri thức.

11. Hoàng Nam (1992), Dân tộc Nùng ở Việt Nam, Nxb Văn hóa dân tộc, Hà Nội.

12. Nhiều tác giả (1994), Ai lên Xúu Lạng, Nxb. Văn hóa Dân tộc, Hà Nội.

13. Nguyễn Quý Thanh chủ biên (2016), Phép đạc tam giác về vốn xã hội của người Việt Nam: mạng luới quan hệ - lòng tin - sự tham gia, Nxb. Đại học Quốc gia Hà Nội.

14. Nguyễn Anh Tuấn (2011), ““'Sổ nợ đời" - vốn xã hội: định đề giới hạn về trao đổi xã hội hay những mối liên hệ liên chủ thể (Tiếp cận Nhân học từ một đám ma ở làng Nùng Phàn Slình, tỉnh Thái Nguyên)", Tạp chí Dân tộc học, số 5 .

15. Lý Viết Trường (2017a), "Một số nghi lễ thời kỳ thơ ấu của người Nùng Phàn Slình, huyện vùng cao biên giới Việt - Trung", Tạp chí Văn hóa các dân tộc, số $5+6$.

16. Lý Viết Trường (2017b), Tri thức dân gian trong quản lý xã hội, Nxb Mỹ Thuật.

17. Lý Viết Trường (2018), Tuơng trọ cộng đồng trong nghi lễ vòng đòi của nguoòi Nùng Phàn Slình (Nghiên cứu ở xã Thạch Đạn, huyện Cao Lộc, tỉnh Lạng Son), Luận văn Thạc sĩ Lịch sử, Đại học Khoa học Xã hội và Nhân văn, ĐHQGHN, Hà Nội.

18. UBND tỉnh Lạng Sơn (1999), Địa chí Lang Son, Nxb. Chính trị Quốc gia, Hà Nội.

19. UBND xã Thạch Đạn (2011), Đề án: xây dựng nông thôn mói xã Thạch Đạn, huyện Cao Lộc, tỉnh Lang Son giai đoạn 2010 - 2020.

20. Viện Dân tộc học (1992), Các dân tộc Tày, Nùng ở Việt Nam, Hà Nội.

21. Viện Dân tộc học (2014), Các dân tộc it ngườ ở Việt Nam (các tỉnh phía Bắc), (tái bản có sữa chữa, bổ sung), Nxb. Khoa học Xã hội, Hà Nội. 


\section{Giving gifts during the childbirth of the Tay, Nung people a form of establishing and maintaining social networks}

Ly Viet Truong

Article info

Recieved:

27/8/2018

Accepted:

10/6/2019

Keywords:

Childbirth gifts;

reciprocity;

social networks

\begin{abstract}
The paper surveys the gift-giving relation of Tay and Nung people during childbirth and its role in establishing and maintaining social networks of people in Thach Dan commune, a typical commune of coexistence and cultural exchanges of the Tay, Nung. Adopting Marcel Mauss's point of view in his work of The Gift, he argues for giving gifts, on the one hand, it is mandatory to give a gift and, on the other, it is mandatory to receive it. Refusing a gift also means refusing a relation. Research results show that during childbirth, the gift-giving relation is based on the principle of "your turn and mine" (reciprocity). Giving gifts during childbirth is a way for the Tay, Nung people in Thach Dan commune to establish, maintain and renew their social capital.
\end{abstract}

